(1500 francs), for a work on zoological palæontology, comparative anatomy, or zoology.

Medicine and Surgery.-Montyon prizes (prize of 2500 francs, mentions of I500 francs), for work contributing to the progress of medicine; the Barbier prize (2000 francs), for a valuable discovery in surgical, medical, pharmaceutical science, or in botany in its relation to medicine; the Breant prize (100,000 francs), for a discovery eradicating Asiatic cholera; the Godard prize (rooo francs), for the best memoir on the anatomy, physiology, and pathology of the urino-genitary organs; the Baron Larrey prize (750 francs), to a physician or surgeon belonging to the Army or Navy for a work treating a subject of military medicine, surgery, or hygiene; the Bellion prize (I 400 francs), for valuable discoveries in medicine or hygiene; the Mege prize (Io,00o francs), to an author who will continue and complete the founder's essay on the causes which have retarded or favoured the progress of medicine; the Argut prize (1200 francs), for a discovery of a cure for a disease at present incapable of treatment by surgery.

Physiology. A Montyon prize (750 francs), for work in experimental physiology; the Philipeaux prize (900 francs), as a recompense for researches in experimental physiology; the Lallemand prize ( 1800 francs), for works relating to the nervous system; the Pourat prize (1000 francs), for researches on the actions exerted by the $\mathrm{X}$-rays and radium rays upon the development and nutrition of living cells.

Statistics.-A Montyon prize (one prize of 1000 francs and two mentions of 500 francs).

History of Science.-The Binoux prize (2000 francs).

General Prizes.-The Arago, Lavoisier, and Berthelot medals; the Henri Becquerel prize (3000 francs); the Gegner prize $(3800$ francs), for researches or work contributing to the progress of science; the Lannelongue prize (2000 francs), for the assistance of scientific workers or their relations in distress; the Gustave Roux prize (10oo francs); the Trémont prize (r roo francs); the Wilde prize (one of 4000 francs and two of 2000 francs), for discoveries in astronomy, physics, chemistry, mineralogy, geology, or experimental mechanics; the Lonchampt prize (4000 francs), for a memoir on the diseases of man, animals, or plants from the special point of view of the introduction of mineral substances in excess as the cause of these diseases; the Saintour prize (3000 francs), for work in mathematics; the Fanny Emden prize (3000 francs), for a work treating of hypnotism, suggestion, or physiological actions exerted at a distance on the animal organism; the Petit d'Ormoy prize (two prizes of 10,000 francs), for work in pure or applied mathematics or natural science; the Pierson-Perrin prize (5000 francs), for an important discovery in mechanics or physics; the Parkin prize (3400 francs), for work on the therapeutic effects of carbon dioxide or on the effects of volcanic action in the production of epidemic diseases; the Estrade-Delcros prize (80oo francs); the Danton prize ( $\mathrm{I}_{5} \mathrm{00}$ francs), for researches relating to radiant phenomena; the prize founded by Mme. la Marquise de Laplace; the Félix Rivot prize (2500 francs).

\section{FORESTRY IN NORWAY.}

THE progress of scientific forestry in Norway forms the subject of an interesting article, by Mr. S. Burtt Meyer, in No. 5 of the Journal of the Board of Agriculture. No less than 2I.4 per cent. of the total area of Norway is under forest, as against 3.9 per cent. in the United Kingdom. The most abundant forest tree is the Scots pine (Pinus Sylvestris), followed by the birch and the spruce $(P$. excelsa). The alder, aspen, and rowan are distributed pretty generally, while the oak, ash, elm, and beech are also found in favoured areas. The commercial timbers, however, are the Scots pine and the spruce, the latter being of great importance since the introduction of the wood-pulp trade. Spruce forms much the best material for wood pulp. A certain amount of pine can be added, but more than about 15 per cent. tends to spoil the colour. Spruce grows at a lower altitude than pine, and, generally speaking, in a more southern latitude. South of Trondhjem the pine usually ceases at about 2600 feet above sea-level, where it is replaced by the birch; above 3500 feet only dwarf birch and willow occur, while at some 4000 feet the snow-line stops all vegetation. The best forest land is that lying in NO. 2202, VOL. 88] the neighbourhood of Christiania extending north and north-east over the Glommen watershed. The management of the forest is on the whole good, and well adapted to the local conditions. The work of felling and removing the timber commences in autumn and continues throughout the winter, being greatly facilitated by the snow which covers the ground from November until March or April.

One common system consists in clearing a circle until its diameter equais the height of the surrounding trees. Labour is obtained largely from the small peasant proprietors, who preponderate so largely in the country. Much attention is devoted to afforestation, two societies, the Royal Society for the Welfare of Norway, and the Norwegian Forestry Society, interesting themselves considerably in this question. Afforestation has naturally received most attention in the coast provinces, but preparatory schemes for land drainage and improvement have also been made for districts in the interior, while planting has been widely carried on over the high-lying Crown lands of eastern Norway. On account of the snowfall, planting is only possible in early summer or early autumn.

Shifting sands on the coast. are planted up in the same manner as on the northern shores of Jylland, in Denmark. Irregularities in the surface are filled in, the ground is then covered with moss, heather, or any kind of loose material, pegged down when necessary, seed of Elymus or Arundo arenaria is sown, and lastly broad strips are planted with Pinus maritima.

THE DEVELOPMENT OF CRYSTAL FACES.

I $N$ a memoir by M. P. Graubert entitled " Recherches récentes sur le Facies des Cristaux," published by the Société de Chimie physique, some remarkable new facts are described regarding the influence of foreign substances on the development of crystal faces. The most interesting relate to the influence of colouring matters, such as methylene blue, eosine, fuchsine, and picric acid, which are shown to be capable of passing into the crystal substance in two different ways. According to one, the colouring matter is deposited on the crystal in the course of growth; this occurs when the solution is saturated with the colouring matter, which thus deposit crystals. An excellent example is afforded by lead nitrate, which when pure usually deposits colourless octahedral crystals. When the mother liquor is saturated with methylene blue, the crystals first deposited exhibit cube faces modifying those of the octahedra, and these cube faces alone are coloured blue; they also exhibit striations like pyrites, corresponding to the faces of the pentagonal dodecahedron. The colour thus not only attaches itself to the faces of a particular form, but indicates the true class of symmetry of the system, in this case a class lower than the holohedral. Similar phenomena are described with gypsum, copper sulphate, thallium sulphate, and morphine, all of which develop specific unusual forms and faces, coloured by the dye, when the latter is methylene blue. Strong polychroism is also introduced in the case of copper sulphate.

The second mode of coloration occurs when a dye stains the crystals grown what ever be the state of dilution of i he dye. Nitrate of urea is a good example. The ordinary crystals are monoclinic tables parallel to the basal plane $\{001\}$, bounded by the prism $\{1 \mathrm{IO}\}$ and pinakoids $\{1 \mathrm{IO}\}$ and $\{0 \mathrm{IO}\}$. But when methylene blue is present the two latter forms are suppressed, and the plates are coloured blue and elongated along the axis of the prism \{IIO'. If, however, picric acid be used as the colouring matter, the facial disposition is entirely altered, the pinakoids being developed, but not the prism. More remarkable still, when both methylene blue and picric acid are present, the crystals of urea nitrate show all four forms, and the plate shows eight sectors, four coloured blue, corresponding to the prism faces, and four yellow opposite the pinakoid faces. Phthalic acid exhibits analogous phenomena with methylene blue, malachite green, and scarlet of Biebrich, specific forms staining with each dye, and the crystal showing differently coloured sectors when the dyes are simultaneously present. The reasons for these remarkable phenomena are not convincingly brought out in the memoir, and it is obvious that an interesting new field of work is opened up, in which much will have to be done before the solution of the problem is satisfactorily achieved. 